\title{
REARING THE SOUTHERN GREEN STINK BUG USING AN ARTIFICIAL DRY DIET AND AN ARTIFICIAL PLANT ${ }^{1}$
}

\author{
ANTÔNIO RICARDO PANIZZI², JOSÉ ROBERTO POSTALI PARRA ${ }^{3}$, \\ CLÁUDIA HIRT SANTOS ${ }^{4}$ and DIOGO RODRIGUES CARVALHO ${ }^{5}$
}

\begin{abstract}
Laboratory and greenhouse studies were conducted with an artificial dry diet to rear nymphs, and with an artificial plant as substrate for egg laying by the southern green stink bug, Nezara viridula (L.). The artificial diet was composed of: soybean protein (15 g); potato starch (7.5 g); dextrose ( $7.5 \mathrm{~g})$; sucrose $(2.5 \mathrm{~g})$; cellulose $(12.5 \mathrm{~g})$; vitamin mixture (niacinamide $1 \mathrm{~g}$, calcium pantothenate $1 \mathrm{~g}$, thiamine $0.25 \mathrm{~g}$, riboflavin $0.5 \mathrm{~g}$, pyridoxine $0.25 \mathrm{~g}$, folic acid $0.25 \mathrm{~g}$, biotin $0.02 \mathrm{~mL}$, vitamin $\mathrm{B}_{12} 1 \mathrm{~g}$ - added to $1,000 \mathrm{~mL}$ of distilled water) $(5.0 \mathrm{~mL})$; soybean oil $(20 \mathrm{~mL})$; wheat germ $(17.9 \mathrm{~g})$; and water $(30 \mathrm{~mL})$. Nymphs showed normal feeding behavior when fed on the artificial diet. Nymphal development time was longer than or similar to that of nymphs fed on soybean pods. Total nymphal mortality was low (ca. 30\%), both for nymphs reared on the artificial diet, and for nymphs fed on soybean pods. At adult emergence, fresh body weights were significantly $(\mathrm{P}<0.01)$ less on the artificial diet than on soybean pods. Despite the lower adult survivorship and fecundity on artificial plants than on soybean plants, it was demonstrated for the first time that a model simulating a natural plant, can be used as a substrate for egg mass laying, in conjunction with the artificial diet.
\end{abstract}

Index terms: Pentatomidae, Nezara viridula, Glycine max, nymphs, oviposition, rearing techniques.

\section{CRIAÇÃO DO PERCEVEJO-VERDE USANDO DIETA ARTIFICIAL SECA E PLANTA ARTIFICIAL}

RESUMO - Foram conduzidos estudos em laboratório e em casa de vegetação, com uma dieta artificial seca para a criação de ninfas e com um modelo de planta artificial como substrato para a colocação de ovos por adultos do percevejo-verde, Nezara viridula (L.). Os componentes da dieta artificial foram: proteína de soja (15 g); fécula de batata (7,5 g); dextrose (7,5 g); sacarose $(2,5 \mathrm{~g})$; celulose $(12,5 \mathrm{~g})$; mistura vitamínica (niacinamida $1 \mathrm{~g}$, pantotenato de cálcio $1 \mathrm{~g}$, tiamina $0,25 \mathrm{~g}$, riboflavina $0,5 \mathrm{~g}$, piridoxina $0,25 \mathrm{~g}$, ácido fólico $0,25 \mathrm{~g}$, biotina $0,02 \mathrm{~mL}$, vitamina $\mathrm{B}_{12} 1 \mathrm{~g}$, adicionada em $1.000 \mathrm{~mL}$ de água destilada) $(5,0 \mathrm{~mL})$; óleo de soja $(20 \mathrm{~mL})$; germe de trigo $(17,9 \mathrm{~g})$; e água $(30 \mathrm{~mL})$. As ninfas alimentaram-se normalmente da dieta, embora o tempo de desenvolvimento tenha sido em um caso, maior, e em outro, semelhante, ao das ninfas que se alimentaram de vagens da soja. A mortalidade total das ninfas foi baixa (ca. 30\%), tanto na dieta como na vagem de soja. Na emergência, os adultos apresentaram peso fresco significativamente $(\mathrm{P}<0,01)$ menor na dieta que na soja. Apesar de a sobrevivência e a fecundidade terem sido menores nas plantas artificiais do que na soja, fica demonstrado, pela primeira vez, que um modelo simulando uma planta natural pode ser usado como substrato para oviposição pelo percevejo $N$. viridula, em conjunto com a dieta artificial.

Termos para indexação: Pentatomidae, Nezara viridula, Glycine max, ninfas, oviposição, técnicas de criação.

\footnotetext{
${ }^{1}$ Accepted for publication on August 17, 2000.

Sponsored by Embrapa-Centro Nacional de Pesquisa de Soja by Conselho Nacional de Desenvolvimento Científico e Tecnológico (CNPq), and by Escola Superior de Agricultura Luiz de Queiroz (ESALQ/USP).

${ }^{2}$ Agronomist, Ph.D., Embrapa-Centro Nacional de Pesquisa de Soja, Caixa Postal 231, CEP 86001-970 Londrina, PR, Brazil. E-mail: panizzi@cnpso.embrapa.br
}

\footnotetext{
${ }^{3}$ Agronomist, Dr., Dep. de Entomologia, Fitopatologia e Zoologia Agrícola, Escola Superior de Agricultura Luiz de Queiroz (ESALQ), Caixa Postal 9, CEP 13418-900 Piracicaba, SP, Brazil. E-mail: jrpparra@ carpa.ciagri.usp.br

${ }^{4}$ Agronomist, graduate student, Dep. de Zoologia, Universidade Federal do Paraná (UFPR), Caixa Postal 19020, CEP 81531-990 Curitiba, PR, Brazil. E-mail: clauhirt@yahoo.com.br

${ }^{5}$ Agronomist, graduate student, ESALQ.

E-mail: drcarval@carpa.ciagri.usp.br
} 


\section{INTRODUCTION}

The southern green stink bug, Nezara viridula (L.) (Hemiptera: Heteroptera: Pentatomidae), is a cosmopolitan bug, causing variable damage to several cultivated plants worldwide (Panizzi et al., 2000). Because of its importance as a pest, several studies have been conducted in many parts of the world, aiming to mitigate its impact on cultivated plants (Jones \& Caprio, 1994; Seymour et al., 1995). Among these studies are those related to rearing $N$. viridula in the laboratory to obtain individuals suitable for bioassays (Corrêa-Ferreira \& Panizzi, 1999).

The first attempts to rear $N$. viridula in the laboratory were conducted using natural foods, such as pods of green beans, Phaseolus vulgaris (L.). The use of green beans plus raw shelled peanuts, Arachis hypogaea (L.), was described by Harris \& Todd (1981) and Jones Junior (1985), and is now worldwide divulged to rear $N$. viridula.

However, not much has been accomplished using artificial diets to rear hemipterans. Jensen \& Gibbens (1973) reported $89.7 \%$ mortality and delayed development of $N$. viridula nymphs fed on a semi-solid artificial diet. Kamano (1980) reared the alydid Riptortus clavatus Thunberg on a dry artificial diet plus water from nymph to adult. For hemipterans that feed on meristematic and developing reproductive tissues and are not seed feeding specialists, e.g., Lygus hesperus Knight and L. lineolaris (Palisot de Beauvois) (Miridae), a meridic liquid diet and an oligidic semiliquid diet were developed and tested with success (Debolt \& Patana, 1985; Cohen, 2000).

The objective of this study was to develop an artificial dry diet to rear the southern green stink bug, $N$. viridula, and to test an artificial (plastic) plant as a model simulating a natural soybean [Glycine max (L.) Merrill] plant, as substrate for egg laying by adults.

\section{MATERIAL AND METHODS}

\section{Artificial diet}

The artificial diet tested (Fig. 1A) was composed of: soybean protein $(15 \mathrm{~g})$; potato starch $(7.5 \mathrm{~g})$; dextrose
(7.5 g); sucrose (2.5 g); cellulose (12.5 g); vitamin mixture (niacinamide $1 \mathrm{~g}$, calcium pantothenate $1 \mathrm{~g}$, thiamine $0.25 \mathrm{~g}$, riboflavin $0.5 \mathrm{~g}$, pyridoxine $0.25 \mathrm{~g}$, folic acid $0.25 \mathrm{~g}$, biotin $0.02 \mathrm{~mL}$, vitamin $\mathrm{B}_{12} 1 \mathrm{~g}$, added to $1,000 \mathrm{~mL}$ of distilled water) $(5.0 \mathrm{~mL})$; soybean oil $(20 \mathrm{~mL})$; wheat germ $(17.9 \mathrm{~g})$; and water $(30 \mathrm{~mL})$. All components were mixed and the diet spread over a plastic lid $(12.0 \mathrm{x} 12.0 \mathrm{x}$ $0.5 \mathrm{~cm}$ ) lined with aluminum foil. While the diet was still soft, small pieces $(0.3 \times 0.3 \mathrm{~cm})$ were cut. The diet was taken to the oven, and dried at $80^{\circ} \mathrm{C}$ for 6 hours before being offered to the nymphs.

\section{Nymph rearing on artificial diet}

During July 1999, egg masses of $N$. viridula from a laboratory colony maintained on soybean plants at the Embrapa-Centro Nacional de Pesquisa de Soja, Londrina, PR, were collected on the day of oviposition and placed in $9.0 \times 1.5 \mathrm{~cm}$ Petri dishes with moistened filter paper. Egg masses were mailed to the Laboratory of Insect Biology at ESALQ/USP, Piracicaba, SP, where the test was also conducted. On the $1^{\text {st }}$ day of the second stadium (first instars do not feed), 30 nymphs were removed, placed individually in Petri dishes and put at random in an incubator maintained at $25 \pm 1^{\circ} \mathrm{C}$ and $65 \pm 5 \%$ RH with a photophase of 14 hours. From August to October 1999, daily observations were made on molting and mortality, and the small cube of diet plus a plastic lid with wet cotton was replaced every two days. Nymphal development times and percentages mortality of each instar and from $2^{\text {nd }}$ instar to adult were calculated.

A similar test was conducted in the Laboratory of Entomology at Embrapa, in Londrina, during April and May 2000.The conditions of this test were similar to those described for the test conducted in Piracicaba, except that in this case the number of nymphs used was $n=29$, and the nymphal development times and mortalities were compared with those of a set of nymphs fed on immature soybean pods $(n=40)$. Data on nymphal development time between both tests using the artificial diet and the soybean pods were compared statistically using Duncan's multiple range test $(\mathrm{P} \leq 0.05)$.

Fresh body weight (mg) at adult emergence of the bugs obtained in Londrina was taken using an electronic balance. Data on fresh body weight were analyzed and compared using Student's t test $(\mathrm{P} \leq 0.05)$.

At emergence, adults obtained from both tests with the artificial diet were recorded as being normal or abnormal. Voucher specimens of adults reared with the diet in Londrina are deposited in the Insect Collection of the Embrapa-Centro Nacional de Pesquisa de Soja. 
Egg laying by adults on artificial plants vs. natural plants

During March 2000, adults of N. viridula were collected in the field on soybean plants growing at the Experimental Farm of the Embrapa-Centro Nacional de Pesquisa de Soja. Adults were taken to the laboratory and placed in plastic rearing boxes $(12.0 \times 12.0 \times 3.8 \mathrm{~cm})$ covered with lids. Because adults were heavily parasitized by tachinid flies, they were kept in the plastic boxes with food (immature soybean pods) for 48 hours, to select the most vigorous and, apparently, unparasitized insects. After this period, adults were taken to an environmental room (maintained at $25 \pm 1{ }^{\circ} \mathrm{C}$ and $65 \pm 10 \% \mathrm{RH}$ with a photophase of 14 hours), and were separated into groups of 50 pairs. Two treatments were set: treatment one consisted of an artificial (plastified tissue) plant (Fig. 1B) plus the artificial diet (small cubes glued on a cardboard tag), which were hung on the plant, plus water supplied from a glass vial with wet cotton; treatment two consisted of a soybean plant with immature pods. In both cases the plants were put in a wooden frame cage $(0.50 \times 0.50 \times 0.50 \mathrm{~m})$ covered with netting. In each case 50 pairs of $N$. viridula were released. Each treatment, set at random, was replicated four times. From April 7 to April 22, 2000, daily observations were made to check for egg masses, which were collected and taken to the laboratory, to record the number of eggs/mass. The number of dead insects were also recorded. The number of egg masses and eggs/plant, and the mean number of egg masses and eggs/day were calculated. Daily survivorship of adults (females and males) was calculated, as well. Data on the fecundity between the two treatments were compared statistically using Student's t test $(\mathrm{P} \leq 0.05)$.

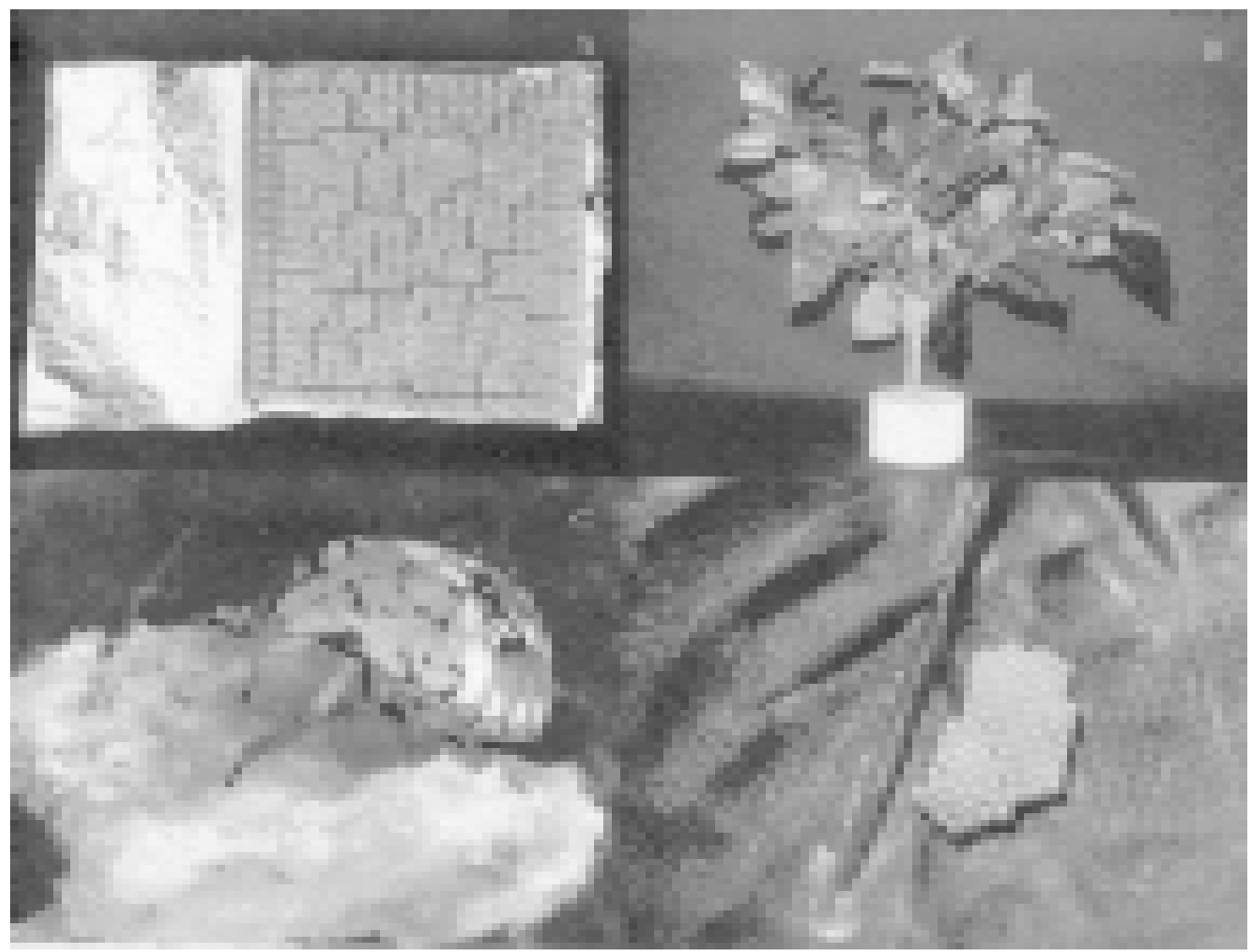

FIG. 1. Artificial diet used to rear nymphs of Nezara viridula (A); artificial plant - a model to mimic a natural soybean plant - used as egg mass substrate (B); a late instar nymph feeding on the artificial diet (C); an egg mass laid on the lower surface of an artificial leaflet (D). 


\section{RESULTS AND DISCUSSION}

\section{Nymph rearing on artificial diet}

Nymphs showed a normal feeding behavior when fed on the artificial diet (Fig. 1C). Nymphal development time for each stadium and for total nymphal period (stadia 2 through 5) was longer for the nymphs fed on the artificial diet (test conducted in Londrina) than when nymphs fed on soybean pods (Table 1). This greater time (ca. 10 days more) taken by nymphs on the artificial diet to complete development was not observed for the test conducted in Piracicaba. In the Piracicaba test, nymphs took about the same time to complete their development (28.7 days) as did nymphs on soybean pods (27.0 days) (Table 1). Delay in nymphal development of $N$. viridula fed on a semi-solid artificial diet compared to natural foods, such as green beans, was previously reported (Jensen \& Gibbens, 1973).

Despite the greater nymphal development time on the artificial diet, observed in one of the tests, the total nymphal mortality was low (ca. 30\%) for nymphs reared on the artificial diet tested in Londrina and in Piracicaba and for nymphs fed on soybean pods (Table 1). This data on nymph mortality is much lower than previous ones obtained with other artificial diets, such as the $90 \%$ mortality of $N$. viridula nymphs reported by Jensen \& Gibbens (1973). The mortality of nymphs obtained is similar to most values reported for $N$. viridula feeding on preferred natural foods (Panizzi, 1997).

At adult emergence, fresh body weights of adults obtained with the artificial diet in Londrina were significantly smaller than the weights observed for adults obtained on soybean pods (Table 2). This may indicate less nutritional quality of the artificial diet than of the natural food (soybean pods). The 21 adults obtained from the artificial diet in Piracicaba were normal. Of the 20 adults obtained in Londrina, 15 (75\%) were normal.

The dry artificial diet tested, based on the diet developed by Kamano (1980) for $R$. clavatus, yielded very good nymphal survivorship (ca. 70\%). Because fruits of Ligustrum lucidum Ait. increase $N$. viridula fecundity by more than three times (Panizzi et al., 1996), lyophilized fruits will be added to the diet in an attempt to improve the diet suitability. Also, the addition of wheat germ, replacing the mixture of aminoacids used in other diets, makes the diet more easily made and much cheaper.

TABLE 1. Mean $( \pm$ SEM) developmental time and mortality $[\%]$ of Nezara viridula nymphs feeding on artificial diet and on immature pods of soybean in the laboratory.

\begin{tabular}{|c|c|c|c|c|c|c|}
\hline \multicolumn{4}{|c|}{ Stadium duration (days) $^{1}$} & \multicolumn{3}{|c|}{ Total developmental time (days) ${ }^{1}$} \\
\hline 2nd & $3 \mathrm{rd}$ & 4th & 5 th & Female & Male & Adults \\
\hline \multicolumn{7}{|c|}{ Artificial diet $(n=29)$} \\
\hline $8.6 \mathrm{a}$ & $9.0 \mathrm{a}$ & $9.0 \mathrm{a}$ & $12.1 \mathrm{a}$ & $39.6 \mathrm{a}$ & $36.6 \mathrm{a}$ & $38.4 \mathrm{a}$ \\
\hline$(0.15)$ & $(0.46)$ & $(0.34)$ & $(0.50)$ & $(1.33)$ & $(1.50)$ & $(1.03)$ \\
\hline [6.9] & [11.1] & [12.5] & {$[4.8]$} & - & - & [31.0] \\
\hline \multicolumn{7}{|c|}{ Artificial $\operatorname{diet}^{2}(n=30)$} \\
\hline $6.2 b$ & $6.2 b$ & $6.1 b$ & $10.7 \mathrm{a}$ & - & - & $28.7 b$ \\
\hline$(0.12)$ & $(0.13)$ & $(0.36)$ & $(0.16)$ & - & - & $(0.26)$ \\
\hline$[0.0]$ & [3.3] & [10.3] & [19.2] & - & - & [30.0] \\
\hline \multicolumn{7}{|c|}{ Soybean pods $(n=40)$} \\
\hline $5.7 \mathrm{~b}$ & $4.7 \mathrm{c}$ & $8.4 \mathrm{a}$ & $9.1 \mathrm{~b}$ & $27.7 b$ & $26.3 b$ & $27.0 \mathrm{~b}$ \\
\hline$(0.21)$ & $(0.43)$ & $(0.66)$ & $(0.55)$ & (1.17) & (1.24) & $(0.85)$ \\
\hline [6.9] & [11.1] & [12.5] & [4.8] & - & - & [30.0] \\
\hline
\end{tabular}


TABLE 2. Mean $( \pm$ SEM) fresh body weight at adult emergence of Nezara viridula reared as nymphs on the artificial diet and on immature soybean pods in the laboratory in Londrina, PR [no. of adults in brackets].

\begin{tabular}{lcc}
\hline Food & \multicolumn{2}{c}{ Fresh body weight $\left(\mathrm{mg}^{1}\right)$} \\
\cline { 2 - 3 } & Female & Male \\
\hline Artificial diet & $158.7 \mathrm{~b}$ & $125.6 \mathrm{~b}$ \\
& $(3.42)[12]$ & $(4.78)[8]$ \\
Soybean pods & $199.5 \mathrm{a}$ & $145.3 \mathrm{a}$ \\
& $(7.35)[13]$ & $(4.03)[15]$ \\
\hline
\end{tabular}

1 Means followed by the same letter in each column do not differ significantly using Student's t test (for females, $\mathrm{t}-\mathrm{value}=6.59 ; \mathrm{P}>\mathrm{t}=0.001$; for males, $\mathrm{t}$-value $=16.38 ; \mathrm{P}>\mathrm{t}=0.001)$

Although liquid diets give good results with N. viridula nymphs and adults (Brewer \& Jones Junior, 1985; Jones Junior \& Brewer, 1987), the dry diet is more easily made and cheaper to use; and it yields equally good results. It seems therefore that a dry diet has greater potential to be widely used, when a source of water is provided.

Egg laying by adults on artificial plants vs. natural plants

The survivorship of field-collected adults exposed to the artificial plants plus diet was lower than those feeding on natural soybean plants (Fig. 2). Females and males found dead in the cages were parasitized by tachinid flies. These results on adult survivorship suggest that the artificial diet was somewhat less nutritional than soybean plants, but additional studies with healthy adults should be conducted to clarify this point.

Similarly, females fed on the artificial diet laid significantly fewer egg masses (Fig. 3) and significantly fewer eggs (Fig. 4) than females fed soybean plants. The mean $( \pm$ SEM) number of egg masses/day on the artificial plant was $6.1 \pm 1.40$, and on the natural plant was $12.3 \pm 2.22$, with a significant difference using Student's t test ( $\mathrm{t}$-value $=2.37$; $\mathrm{P}>\mathrm{t}=0.024)$. The mean $( \pm$ SEM $)$ number of eggs/day on the artificial plant was 472.8 \pm 123.76 , and on the natural plant was $1061.3 \pm 175.60$, with a

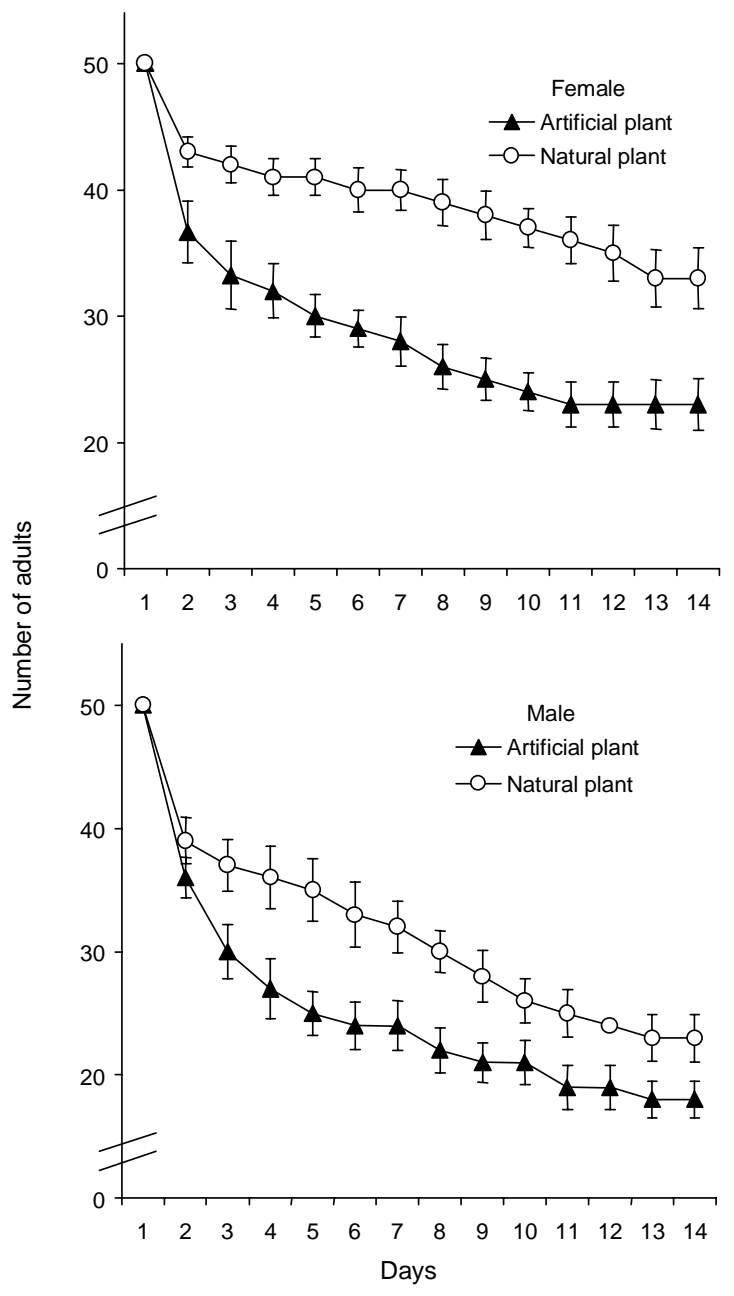

FIG. 2. Survivorship up to 2-weeks of female and male Nezara viridula feeding on artificial diet in the presence of artificial plant, compared with adults fed on soybean pods of natural plants.

significant difference using Student's t test $(\mathrm{t}$-value $=2.74 ; \mathrm{P}>\mathrm{t}=0.011)$. The peak of fecundity occurred on the $3^{\text {rd }}$ day on the artificial plants, whereas on natural plants it occurred on the $1^{\text {st }}$ day. This may be explained by the fact that adults took longer time to adapt to the artificial plant, before starting to lay eggs. However, these results demonstrate, for the first time, that a model simulating a natural plant can be used as a substrate for egg mass deposition by $N$. viridula. Egg masses were always laid on 
the lower surface of the artificial plant leaflets (Fig. 1D), in a pattern resembling the oviposition behavior showed by females on natural plants. The egg masses deposited on the artificial plants were easily detached from the plants. Also, the bugs behaved on the artificial plants the same way as they do on natural plants. These results suggest that the bugs will lay the eggs on the artificial plant based on its color (green) and shape (architecture), this gov-

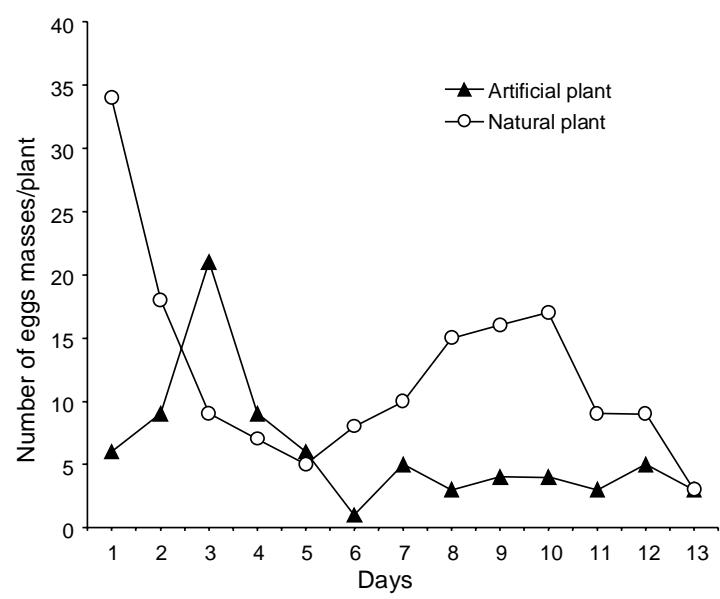

FIG. 3. Number of egg masses laid by Nezara viridula females feeding on artificial diet in the presence of artificial plant, compared with females fed on soybean pods of natural plants.

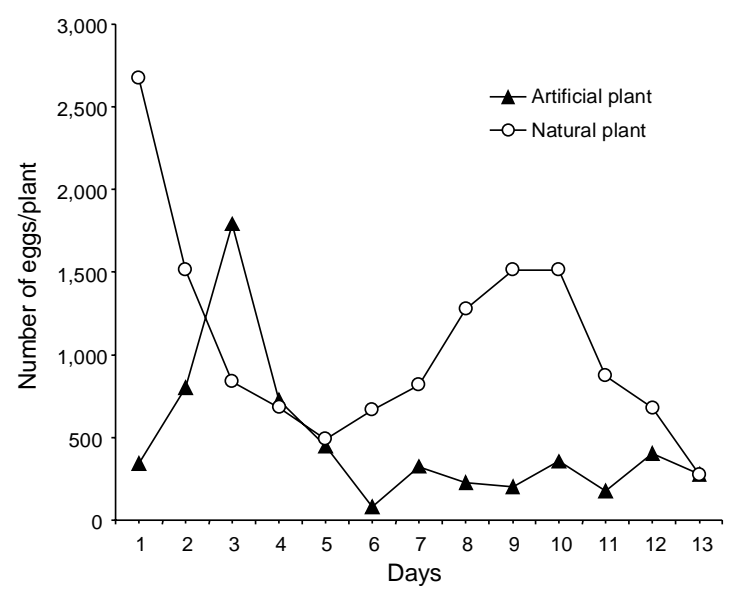

FIG. 4. Number of eggs laid by Nezara viridula females feeding on artificial diet in the presence of artificial plant, compared with females fed on soybean pods of natural plants. erned by visual stimuli, independently of chemical cues. These results are in accordance with a recent theory on host-plant selection by insects (Finch \& Collier, 2000).

The use of artificial plants for egg mass deposition by $N$. viridula is feasible, and has several advantages, when compared to natural plants. Among these are: no need to use pots, earth, and seeds; no need to use greenhouse facilities; no need to spray plants against mites and other greenhouse pests; artificial plants can be used more than one time and at any time, in contrast to natural plants that need to grow and reproduce to become suitable for the bugs; artificial plants are much more easily handled, and their use is cheaper. Therefore, artificial plants show great potential to replace natural plants for housing N. viridula.

\section{CONCLUSIONS}

1. The artificial dry diet described here provides satisfactory survivorship of $N$. viridula nymphs (70\%), despite the delayed nymphal development time and lower fresh body weight of adults at emergence, compared to nymphs fed on soybean pods.

2. Artificial (plastified tissue) plants can be used as a substrate for egg laying by $N$. viridula with success, adults showing a similar general behavior as when on natural plants.

3. Artificial plants combined with adequate artificial diet present several advantages for maintaining $N$. viridula colonies, when compared to natural plants, such as soybean.

\section{ACKNOWLEDGEMENTS}

To Carl W. Schaefer, Norman Neumaier, and two anonymous reviewers for revising an early version of the manuscript.

\section{REFERENCES}

BREWER, F.D.; JONES JUNIOR, W.A. Comparison of meridic and natural diets on the biology of Nezara viridula (Heteroptera: Pentatomidae) and eight other phytophagous Heteroptera. Entomological Society of America. Annals, Lanham, v.78, n.5, p.620-625, 1985. 
COHEN, A.C. New oligidic production diet for Lygus hesperus Knight and L. lineolaris (Palisot de Beauvois). Journal of Entomological Science, Clemson, v.35, n.3, p.301-310, 2000.

CORRÊA-FERREIRA, B.S.; PANIZZI, A.R. Percevejos da soja e seu manejo. Londrina : Embrapa-CNPSo, 1999. 45p. (Embrapa-CNPSo. Circular Técnica, 24).

DEBOLT, J.W.; PATANA, R. Lygus hesperus. In: SINGH, P.; MOORE, R.F. (Ed.). Handbook of insect rearing. Amsterdam : Elsevier Science, 1985, p.329-338.

FINCH, S.; COLLIER, R.H. Host-plant selection by insects: a theory based on "appropriate/inappropriate landings" by pest insects of cruciferous plants. Entomologia Experimentalis et Applicata, Dordrecht, v.96, n.1, p.91-102, 2000.

HARRIS, V.E.; TODD, J.W. Rearing the southern green stink bug, Nezara viridula, with relevant aspects of its biology. Georgia Entomological Society Journal, Athens, v.16, n.2, p.203-210, 1981.

JENSEN, R.L.; GIBBENS, J. Rearing the southern green stink bug on an artificial diet. Journal of Economic Entomology, Lanham, v.66, n.1, p.269-271, 1973.

JONES, V.P.; CAPRIO, L.C. Southern green stink bug (Hemiptera: Pentatomidae) feeding on Hawaiian macadamia nuts: the relative importance of damage occurring in the canopy and on the ground. Journal of Economic Entomology, Lanham, v.87, n.2, p.431435, 1994.

JONES JUNIOR, W.A. Nezara viridula. In: SINGH, P.; MOORE, R.F. (Ed.). Handbook of insect rearing. Amsterdam : Elsevier Science, 1985. p.339-343.
JONES JUNIOR, W.A.; BREWER, F.D. Suitability of various host plant seeds and artificial diets for rearing Nezara viridula (L.). Journal of Agricultural Entomology, Clemson, v.4, n.3, p.223-232, 1987.

KAMANO, S. Artificial diet for rearing bean bug, Riptortus clavatus Thunberg. Japanese Journal of Applied Entomology and Zoology, Tokyo, v.24, n.3, p.184188,1980

PANIZZI, A.R. Wild hosts of pentatomids: ecological significance and role in their pest status on crops. Annual Review of Entomology, Palo Alto, v.42, p.99122, 1997.

PANIZZI, A.R.; McPHERSON, J.E.; JAMES, D.G.; JAVAHERY, M.; McPHERSON, R.M. Economic importance of stink bugs (Pentatomidae). In: SCHAEFER, C.W.; PANIZZI, A.R. (Ed.) Heteroptera of economic importance. Boca Raton : CRC, 2000. p.421-474.

PANIZZI, A.R.; VIVAN, L.M.; CORRÊA-FERREIRA, B.S.; FOERSTER, L.A. Performance of southern green stink bug (Heteroptera: Pentatomidae) nymphs and adults on a novel food plant (Japanese privet) and other hosts. Entomological Society of America. Annals, Lanham, v.89, n.6, p.822-827, 1996.

SEYMOUR, J.; BOWMAN, G.; CROUCH, M. Effects of neem tree extract on feeding frequency of Nezara viridula L. (Hemiptera: Pentatomidae) on pecan nuts. Australian Entomological Society. Journal, Carlton South, v.34, n.1, p.221-223, 1995. 